Southern Illinois University Carbondale

OpenSIUC

Publications

Fisheries and Illinois Aquaculture Center

$1-2007$

\title{
Comparative Fatty Acid Composition of Eggs from White Bass Fed Live Food or Commercial Feed
}

Ryan L. Lane

Christopher C. Kohler

Southern Illinois University Carbondale

Follow this and additional works at: http:// opensiuc.lib.siu.edu/fiaq pubs

(C) by the American Fisheries Society 2007

Published in North American Journal of Aquaculture, Vol. 69, Issue 1 (January 2007) at doi: 10.1577/

A06-014.1

Communication.

\section{Recommended Citation}

Lane, Ryan L. and Kohler, Christopher C. "Comparative Fatty Acid Composition of Eggs from White Bass Fed Live Food or Commercial Feed." (Jan 2007).

This Article is brought to you for free and open access by the Fisheries and Illinois Aquaculture Center at OpenSIUC. It has been accepted for inclusion in Publications by an authorized administrator of OpenSIUC. For more information, please contact opensiuc@lib.siu.edu. 


\title{
Comparative Fatty Acid Composition of Eggs from White Bass Fed Live Food or Commercial Feed
}

\author{
Ryan L. Lane and Christopher C. Kohler* \\ Fisheries and Illinois Aquaculture Center and Department of Zoology, Southern Illinois University, \\ Carbondale, Illinois 62901-6511, USA
}

\begin{abstract}
We evaluated the influence of two broodstock feeding practices on fatty acid composition and viability of eggs in white bass Morone chrysops. The two dietary groups tested were (1) white bass females fed a commercially formulated feed (crude protein, 45\%; crude fat, 16\%) and (2) white bass females maintained on live food (fathead minnow Pimephales promelas and golden shiners Notemigonus crysoleucas). Significant differences existed between the dietary treatments in egg fatty acid levels. Eggs of white bass fed live food contained more 11-octadecenoic acid (18:1[n-7]), $\alpha$-linolenic acid (18:3[n-3]), arachidonic acid (20:4[n-6]), docosahexaenoic acid (22:6[n-3]), and total n-3 fatty acids than eggs of fish fed formulated feed. Conversely, eggs of fish fed the formulated feed contained more oleic acid (18:1[n-9]), linoleic acid (18:2[n-6]), and total monoeic acids. Female white bass fed live food produced significantly more viable eggs $(68.0 \pm 2.0 \%)$ at $48 \pm 2 \mathrm{~h}$ posthatch than did females fed the commercial feed $(57.0 \pm 2.0 \%$ [mean \pm $\mathrm{SD}])$. We found that the egg fatty acids of white bass are significantly affected by the diet of the female and suggest that the fatty acid composition of eggs contribute to overall reproductive success and viability of progeny. More information on the nutrient requirements of piscivorous broodstock is needed to allow feeds to be formulated to enhance the viability of eggs and fry.
\end{abstract}

Nutrition has significant effects on ovarian growth, fecundity, and progeny robustness (Mourente and Odriozola 1990; Harel et al. 1994; Mazorra et al. 2003); however, broodstock nutrition is poorly understood and scantly researched for many aquacultured species (Izquierdo et al. 2001). In particular, more information on nutrient requirements of piscivorous broodstock is needed to allow feeds to be formulated to enhance the viability of eggs and fry (Bromage 1995).

Among the dietary constituents of prepared feeds, dietary lipids and their fatty acids are critical for the overall reproductive performance of the female as well as progeny development and survival during yolk sac resorption (Cerdá et al. 1995; Fernández-Palacios et al. 1995, 1997; Bell et al. 1997; Navas et al. 1997; Bruce et al. 1999; Mazorra et al. 2003). Essential fatty acids

\footnotetext{
* Corresponding author: ckohler@siu.edu
}

Received February 23, 2006; accepted June 23, 2006 Published online December 7, 2006
(EFAs), especially long-chain highly unsaturated fatty acids (HUFAs), namely eicosapentaenoic acid (20:5[n3]; EPA) ${ }^{1}$ and docosahexaenoic acid (22:6[n-3]; DHA), are strongly associated with reproductive success of fishes (March 1993). The n-3 HUFAs are important for membrane formation and properties, specifically fluidity and permeability and provision of vital precursors for the synthesis of cell-signaling messengers (Bell et al. 1986). Several authors have confirmed the importance of an adequate supply of EFAs to broodstock during vitellogenesis, when the demand for lipids is the greatest (Sargent 1995; Navas et al. 1997). Although some organisms can synthesize EPA and DHA de novo to satisfy their EFA requirements, many fish lack adequate enzymatic function to produce these fatty acids at a rate sufficient to meet nutrient requirements. In the case of broodstock, the requirement for dietary EFAs is most likely greatest from a previtellogenic period to ovulation. Therefore, EPA and DHA are often supplemented in diets of broodstock for normal growth and development of progeny (March 1993; Sargent et al. 1995).

Feeding live food sources (e.g., minnow Pimephales spp. and golden shiners Notemigonus crysoleucas) has proven to be an effective strategy to satisfy the EFA requirements of broodfish. An effective formulated feed for broodfish would, however, reduce production costs, simplify feed management, and eliminate a potential pathogen source in culture facilities. Moreover, these feeds may potentially outperform live foods (nutritionally), ensuring the supply and continuity of viable progeny to the aquaculture industry. Further knowledge of nutritional factors responsible for reproductive success associated with natural recruitment is needed to develop a broodstock diet and the continued success of fingerling production. Therefore, the objective of this study was to evaluate the reproductive performance of a broodstock of white bass Morone chrysops, egg fatty acid compositions,

\footnotetext{
${ }^{1}$ In this notation, the number to the left of the colon is the number of carbon atoms in the compound, the number immediately to the right of the colon is the number of double bonds, and the number after the hyphen indicates the position of the first double bond from the methyl end.
} 
and viability of progeny produced from female white bass fed either live food or a commercial diet.

\section{Methods}

Mature wild white bass females $(\sim 100$ individuals; weight range, $0.5-0.9 \mathrm{~kg}$ ) collected from the Arkansas River were maintained for approximately 2 months in raceways (11,000 L) supplied with degassed well water at Keo Fish Farms, Inc. (Keo, Arkansas), on live food (fathead minnow $P$. promelas and golden shiners). Females were subsequently divided into two dietary treatments: (1) feed-trained and fed a commercial feed (crude protein, 45\%; crude fat, 16\%) and (2) maintained on the same live food. After approximately 2 months, all females were injected intramuscularly with $150-\mathrm{IU} / \mathrm{kg}$ human chorionic gonadotropin to induce a synchronous ovulation period (Suresh et al. 2000); all ovulated within a 4-h period. Upon ovulation, five replicate groups of five similar size females per dietary treatment $(N=5)$ were weighed (nearest $0.1 \mathrm{~kg}$ ) and measured (nearest centimeter) and then rapidly stripped ( $\sim 2 \mathrm{~min})$. Eggs were immediately pooled in a plastic bowl, treated with a tannic acid solution to reduce their adhesiveness (Rottmann et al. 1988), and then fertilized with spermatozoa of striped bass $M$. saxatilis. Eggs from each replicate group per treatment were incubated $\left(\sim 20^{\circ} \mathrm{C}\right)$ in MacDonald jars until hatch at $48 \pm 2 \mathrm{~h}$ postfertilization. Total volume $(\mathrm{mL})$ of eggs was recorded for each of the five replicate groups. Fecundity (eggs/kg) was determined from the pooled egg samples and the total group weight of the replicate (five females/group) for all replicates within both dietary treatments.

Samples of fertilized eggs were collected at two time periods during the study: (1) before tannic acid treatment and (2) after tannic acid treatment. Before antiadhesive treatment and after microscopic examination, 100 normal eggs per group replicate for both treatments were collected (within 2 min postfertilization) and immediately frozen in 5-mL plastic cryovials using liquid nitrogen $\left(-196^{\circ} \mathrm{C}\right)$ to ensure quality samples for biochemical comparison. All egg samples were held in liquid nitrogen until blanketed with ultrapure nitrogen and placed into a $-80^{\circ} \mathrm{C}$ freezer for later lipid analysis. After egg antiadhesive treatment, 1.0-mL samples were removed from MacDonald jars, counted, and observed microscopically to calculate egg diameter $(\mu \mathrm{m})$ and egg viability $(\%)$, the latter determined as the percentage of morphologically normal eggs within $1 \mathrm{~h}$ postfertilization and at $48 \pm$ $2 \mathrm{~h}$ postfertilization from each treatment group replicate. Total lengths $(\mathrm{mm})$ of 30 randomly selected fry (live) from each experimental group were measured at $1,2,3$, and $4 \mathrm{~d}$ posthatch (DPH).
After separate homogenization of feed, live food, and female broodfish of each treatment using an Omni mixer homogenizer (Omni International, Waterbury, Connecticut), lipid was extracted in a 2:1 solution of chloroform and methanol (volume per volume) containing $0.01 \%$ (weight per volume) butylated hydroxytoluene following the method of Folch et al. (1957). Lipid samples were subjected to acid-catalyzed transmethylation performed overnight at $50^{\circ} \mathrm{C}$ as described previously by Christie (1982). The resultant fatty acid methyl esters (FAMEs) were separated with a Shimadzu GC-17A gas chromatograph (Shimadzu Scientific Instruments, Kyoto, Japan) equipped with a flame ionization detector fitted with an Omegawax 250 fused silica capillary column (Sigma-Aldrich Corporation, St. Louis, Missouri; $30 \mathrm{~m} \times 0.25 \mathrm{~mm}$ inside diameter; $0.25-\mu \mathrm{m}$ film). A splitless injection technique (100:1) was used and the temperature program was as follows: $50^{\circ} \mathrm{C}$ held for $2 \mathrm{~min}$, increased to $148^{\circ} \mathrm{C}$ at $10^{\circ} \mathrm{C} / \mathrm{min}, 148^{\circ} \mathrm{C}$ held for $5 \mathrm{~min}$, increased to $220^{\circ} \mathrm{C}$ at $4^{\circ} \mathrm{C} / \mathrm{min}$, and held at $220^{\circ} \mathrm{C}$ for $15 \mathrm{~min}$. Individual FAMEs were qualified and quantified by reference to external standards (Supelco 37 component FAME mix, polyunsaturated fatty acid [PUFA]-1, and PUFA-3; Sigma-Aldrich) and an internal standard (23:0, SigmaAldrich).

Data on female weight $(\mathrm{kg})$, length $(\mathrm{cm})$, condition ([weight/length $\left.\left.{ }^{3}\right] \times 10,000\right)$, fecundity (eggs/kg), egg viability (\%), lengths of fry from $1 \mathrm{DPH}$ to $4 \mathrm{DPH}$, as well as fatty acid data were subjected to analysis of variance using the mixed model in SAS (SAS Institute 2001). Replicate groups $(N=5)$ of females (25 fish/ dietary treatment) were classified as experimental units, and variation among experimental units nested within dietary treatment was used as the experimental error in tests for significance; individual fish were not classified as an independent factor in the statistical analyses. Significance was considered at $P \leq 0.05$.

\section{Results and Discussion}

We found marked differences in the fatty acid composition of eggs produced from female white bass fed live food rather than a commercial feed (Table 1). Eggs produced by broodstock fed live food contained more 11-octadecenoic acid (18:1[n-7]), $\alpha$-linolenic acid (18:3[n-3]), arachidonic acid (20:4[n-6]; ARA), DHA (22:6[n-3]), and total n-3 fatty acids than did eggs of fish fed a commercial feed. Although not statistically significant, mean total HUFA quantities and a higher n3:n-6 ratio existed in eggs produced by the female white bass fed live foods than occurred in eggs produced by the female white bass fed the commercial feed. Eggs of fish fed the commercial feed contained more oleic $(18: 1[n-9])$, linoleic $(18: 2[n-6])$, and total 
TABLE 1.-Mean values and pooled SEs of the mean from replicate groups $(N=5)$ of pooled-egg fatty acids (\% of total fatty acid methyl esters) at fertilization produced by Arkansas River white bass fed a commercial feed or maintained on live food (fathead minnow and golden shiners). Within rows, values with different lowercase letters are significantly different $(P<0.05)$. Highly unsaturated fatty acids (HUFAs) are included.

\begin{tabular}{lrrr}
\hline Fatty acid $^{\mathrm{a}}$ & Live food & Commercial feed & SE \\
\hline $14: 0$ & $5.5 \mathrm{z}$ & $6.2 \mathrm{z}$ & 0.6 \\
$16: 0$ & $21.6 \mathrm{z}$ & $20.3 \mathrm{z}$ & 1.3 \\
$18: 0$ & $2.6 \mathrm{z}$ & $2.5 \mathrm{z}$ & 0.1 \\
Total saturates $^{\mathrm{b}}$ & $30.8 \mathrm{z}$ & $29.5 \mathrm{z}$ & 1.6 \\
$16: 1(\mathrm{n}-7)$ & $14.1 \mathrm{z}$ & $13.7 \mathrm{z}$ & 0.5 \\
$18: 1 \mathrm{n}-9)$ & $13.7 \mathrm{z}$ & $18.2 \mathrm{y}$ & 0.9 \\
$18: 1(\mathrm{n}-7)$ & $5.1 \mathrm{z}$ & $4.0 \mathrm{y}$ & 0.2 \\
Total monoenes $^{\mathrm{c}}$ & $33.4 \mathrm{z}$ & $36.5 \mathrm{y}$ & 0.9 \\
$18: 2(\mathrm{n}-6)$ & $3.5 \mathrm{z}$ & $7.7 \mathrm{y}$ & 1.3 \\
$20: 4(\mathrm{n}-6)$ & $4.0 \mathrm{z}$ & $2.3 \mathrm{y}$ & 0.3 \\
Total $\mathrm{n}-6^{\mathrm{d}}$ & $8.0 \mathrm{z}$ & $11.3 \mathrm{z}$ & 1.0 \\
$18: 3(\mathrm{n}-3)$ & $4.1 \mathrm{z}$ & $2.0 \mathrm{y}$ & 0.5 \\
$18: 4(\mathrm{n}-3)$ & $5.0 \mathrm{z}$ & $4.8 \mathrm{z}$ & 0.5 \\
$20: 5(\mathrm{n}-3)$ & $5.9 \mathrm{z}$ & $5.7 \mathrm{z}$ & 0.5 \\
$22: 5(\mathrm{n}-3)$ & $1.5 \mathrm{z}$ & $1.3 \mathrm{z}$ & 0.2 \\
$22: 6(\mathrm{n}-3)$ & $10.4 \mathrm{z}$ & $7.8 \mathrm{y}$ & 0.7 \\
Total $\mathrm{n}-3^{\mathrm{e}}$ & $27.8 \mathrm{z}$ & $22.0 \mathrm{y}$ & 1.7 \\
HUFAs & $22.8 \mathrm{z}$ & $17.5 \mathrm{z}$ & 1.6 \\
n-3:n-6 ratio & $3.5 \mathrm{z}$ & $2.4 \mathrm{z}$ & 0.4 \\
\hline
\end{tabular}

${ }^{a}$ In the notation used in this column, the number to the left of the colon is the number of carbon atoms in the compound, the number immediately to the right of the colon is the number of double bonds, and the number after the hyphen indicated the position of the first double bond from the methyl end.

${ }^{\mathrm{b}}$ Includes 15:0, 17:0, 20:0, 22:0, and 24:0.

${ }^{\mathrm{c}}$ Includes 20:1(n-9), 22:1(n-11), 22:1(n-9), and 24:1(n-9).

${ }^{\mathrm{d}}$ Includes 18:3(n-6), 20:2(n-6), 20:3(n-6), and 22:2(n-6).

${ }^{\mathrm{e}}$ Includes 20:3(n-3) and 20:4(n-3)

${ }^{\mathrm{f}}$ Includes fatty acids with carbon chain length of 20 or more and 3 or more double bonds.

monoeic acids compared with eggs of the other dietary treatment. Similar results with dietary lipid and egg fatty acids, specifically higher levels of unsaturated fats in eggs from female parents consuming live food, were found in previous studies with striped bass (Harrell and Woods 1995; Gallagher et al. 1998), Atlantic halibut Hippoglossus hippoglossus (Mazorra et al. 2003), gilthead seabream (also known as gilthead bream) Sparus auratus (Mourente and Odriozola 1990; Fernández-Palacios et al. 1995, 1997; Almansa et al. 1999), and sea bass Dicentrarchus labrax (also known as the European bass Morone labrax; Bell et al. 1997; Navas et al. 1997; Bruce et al. 1999).

In previous studies with sea bass, Cerdá et al. (1995), Bell et al. (1997), and Bruce et al. (1999) observed differences in egg fatty acids and a marked reduction in the survival of eggs from females fed commercial diets compared with females fed live food diets containing higher n-3 HUFAs. Significant differences $(P<0.05)$ existed in egg viability between the two experimental
TABLE 2.-Mean values of replicate subsamples $(N=5)$ of fatty acids (\% of total fatty acid methyl esters) represented in the live food (fathead minnow and golden shiners) and commercial feed (crude protein, $45 \%$; crude fat, $16 \%$ ) fed to replicate groups of female white bass. Within rows, values with different lowercase letters are significantly different $(P<$ 0.05). Highly unsaturated fatty acids (HUFAs) are included.

\begin{tabular}{lrr}
\hline Fatty acid $^{\mathrm{a}}$ & Live food & Commercial feed \\
\hline $14: 0$ & $0.7 \mathrm{z}$ & $7.4 \mathrm{y}$ \\
$16: 0$ & $19.2 \mathrm{z}$ & $23.8 \mathrm{y}$ \\
$18: 0$ & $6.3 \mathrm{z}$ & $5.4 \mathrm{y}$ \\
$16: 1(\mathrm{n}-7)$ & $3.0 \mathrm{z}$ & $9.2 \mathrm{y}$ \\
$18: 1(\mathrm{n}-9)$ & $22.3 \mathrm{z}$ & $15.9 \mathrm{y}$ \\
$18: 1(\mathrm{n}-7)$ & $3.2 \mathrm{z}$ & $3.2 \mathrm{z}$ \\
$18: 2(\mathrm{n}-6)$ & $10.4 \mathrm{z}$ & $9.0 \mathrm{z}$ \\
20:4(n-6) (ARA) & $9.1 \mathrm{z}$ & $1.0 \mathrm{y}$ \\
$18: 3(\mathrm{n}-3)$ & $1.4 \mathrm{z}$ & $1.5 \mathrm{z}$ \\
$18: 4(\mathrm{n}-3)$ & $0.1 \mathrm{z}$ & $1.6 \mathrm{y}$ \\
$20: 5(\mathrm{n}-3)$ (EPA) & $3.5 \mathrm{z}$ & $8.8 \mathrm{y}$ \\
$22: 5(\mathrm{n}-3)$ & $2.1 \mathrm{z}$ & $1.6 \mathrm{y}$ \\
$22: 6(\mathrm{n}-3)$ (DHA) & $12.4 \mathrm{z}$ & $7.0 \mathrm{y}$ \\
ARA: EPA ratio & $2.6 \mathrm{z}$ & $0.1 \mathrm{y}$ \\
ARA : DHA ratio & $0.7 \mathrm{z}$ & $0.1 \mathrm{y}$ \\
DHA: EPA ratio & $3.5 \mathrm{z}$ & $0.8 \mathrm{y}$ \\
HUFAs & $29.6 \mathrm{z}$ & $19.5 \mathrm{y}$ \\
\hline
\end{tabular}

${ }^{a}$ See Table 1 for an explanation of the numerical notation used in this column. Certain fatty acids are also designated by acronyms, namely, arachidonic acid (ARA), eicosapentaenoic acid (EPA), and docosahexaenoic acid (DHA).

${ }^{\mathrm{b}}$ Includes fatty acids with carbon chain length of 20 or more and 3 or more double bonds.

groups in this study. Female white bass fed live food produced significantly more viable eggs $(68.0 \pm 2.0 \%$ $[$ mean $\pm \mathrm{SD}])$ at $48 \pm 2 \mathrm{~h}$ postfertilization than did eggs produced by female broodstock fed the commercial feed $(57.0 \pm 2.0 \%)$. Harrell and Woods (1995) also found eggs of wild-caught striped bass possessed higher DHA and n-3 HUFA levels than did eggs of domestic striped bass fed a commercial feed, but did not observe adverse effects with subsequent larval survival up to exogenous feeding. In this study, no differences existed in fecundity $(270,000 \pm 47,000$ and 250,000 $\pm 47,000 \mathrm{eggs} / \mathrm{kg})$, female weight $(0.7 \pm$ 0.2 and $0.6 \pm 0.2 \mathrm{~kg})$, female length $(33.0 \pm 0.6$ and $31.0 \pm 0.6 \mathrm{~cm})$, or fry lengths at $1,2,3$, or $4 \mathrm{DPH}$ between females fed live food and commercial feed, respectively.

The live food feeding regime clearly provided, among others, higher levels of HUFAs, particularly in ARA and DHA content, than did the commercial feed (Table 2). As discussed previously, n-3 HUFAs, chiefly DHA, have pronounced effects on reproductive performance and neural development of progeny (Bell et al. 1985; Tocher and Harvie 1988; Bell and Dick 1991; Sargent et al. 1995). Additionally, the importance of ARA as an EFA for broodstock fish is recognized (Bell et al. 1997; Gallagher et al. 1998). 
Moreover, ARA is a physiologically important HUFA of the $n-6$ series, possessing a vital function as a precursor for a class of biologically active compounds known as eicosanoids (Tocher and Sargent 1987). Specifically, ARA-derived eicosanoids have been suggested as being important in modulation of ovulation (Mustafa and Srivastava 1989) and are most likely involved in embryogenesis, hatching, and production of robust eggs and fry. Dietary ARA levels show a correlation with fertilization rates in gilthead seabream broodstock (Fernández-Palacios et al. 1995, 1997). Mazorra et al. (2003) indicated dietary levels of ARA at $1.8 \%$ of total fatty acids improved reproductive success and egg and fry robustness in Atlantic halibut. Improved performance of broodstock fed higher levels of HUFAs observed in this study could be attributable to the increased availability of ARA in the maternal diet. Similar results have been indicated with other species (Cerdá et al. 1995; Bell et al. 1997; Bruce et al. 1999), suggesting a low enzymatic activity to elongate and desaturate dietary 18:2(n-6) to ARA associated with these species. The absolute dietary requirement for ARA, coupled with its potential synergies with other long-chain HUFAs in teleost reproduction, however, has not been adequately addressed (Gallagher et al. 1998) and warrants further investigation.

To date, the most effective way to satisfy the EFA requirements of broodstock has been through the use of live food sources because few reliable alternatives are available to producers. Certainly, live foods have proved an effective way of meeting nutritional requirements of broodstock and ensuring quality gametes. However, live food sources have been implicated as a route for the inadvertent introduction of pathogens to culture facilities. Therefore, commercial interests, especially those maintaining Morone spp. broodstock, have expressed a desire for an effective formulated feed to reduce production costs and to simplify broodstock management. To be effective, however, a broodstock diet must meet the endogenous developmental demand of their progeny for long-chain HUFAs before the onset of exogenous feeding by fry. Ultimately, additional work conducted with isocaloric, isonitrogenous diets may lead to diet formulations that not only meet the specific nutritional requirements of broodfish, but also optimize reproductive success by enhancing egg and fry viability.

\section{Acknowledgments}

We thank Mike Freeze and Mike Clark of Keo Fish Farms, Inc., for use of their facilities and broodfish as well as sharing their knowledge of Morone spp. spawning. This study was conducted by the first author as part of a dissertation to partially meet the requirements for a Doctor of Philosophy degree in the Department of Zoology, Southern Illinois University at Carbondale. The material is based upon work supported, in part, by the National Science Foundation under Grant No. 0227925. Any opinions, findings, and conclusions or recommendations expressed in this material are those of the authors and do not necessarily reflect the views of the National Science Foundation. This publication is also a result of work sponsored, in part, by the North Central Regional Aquaculture Center Program under grant 2001-38500-5863 from the U.S. Department of Agriculture. The U.S. Government and the North Central Regional Aquaculture Center are authorized to produce and distribute reprints for governmental purposes notwithstanding any copyright notation appearing herein. Reference to trade names does not imply endorsement by the U.S. Government.

\section{References}

Almansa, E., M. J. Pérez, J. R. Cejas, P. Badía, J. E. Villamandos, and A. Lorenzo. 1999. Influence of broodstock gilthead seabream (Sparus aurata L.) dietary fatty acids on egg quality and egg fatty acid composition throughout the spawning season. Aquaculture 170:323-336.

Bell, M. V., and J. R. Dick. 1991. Molecular species composition of the major diacyl glycerophospholipids from muscle, liver, retina, and brain of cod (Gadus morhua). Lipids 26:565-573.

Bell, J. G., B. M. Farndale, M. P. Bruce, J. M. Navas, and M. Carillo. 1997. Effects of broodstock dietary lipid on fatty acid compositions of eggs from sea bass (Dicentrarchus labrax). Aquaculture 149:107-119.

Bell, M. V., R. J. Henderson, B. J. S. Pirie, and J. R. Sargent. 1985. Effects of dietary polyunsaturated fatty acids on mortality, growth, and gill structure in the turbot, Scophthalmus maximus. Journal of Fish Biology 26: 181-191.

Bell, M. V., R. J. Henderson, and J. R. Sargent. 1986. The role of polyunsaturated fatty acids in fish. Comparative Biochemistry and Physiology 83B:711-719.

Bromage, N. R. 1995. Broodstock management and seed quality: general considerations. Pages 1-24 in N. R. Bromage and J. R. Roberts, editors. Broodstock management and egg and larval quality. Blackwell Scientific Publications, London.

Bruce, M., F. Oyen, G. Bell, J. F. Asturiano, B. Farndale, M. Carrillo, S. Zanuy, J. Ramos, and N. Bromage. 1999. Development of broodstock diets for the European sea bass (Dicentrarchus labrax) with special emphasis on the importance of n-3 and n-6 highly unsaturated fatty acids to reproductive performance. Aquaculture 177:85-97.

Cerdá, J., S. Zanuy, M. Carrillo, J. Ramos, and R. Serrano. 1995. Short- and long-term dietary effects on female sea bass (Dicentrarchus labrax): seasonal changes in plasma profiles of lipids and sex steroids in relation to reproduction. Comparative Biochemistry and Physiology 111C:83-91.

Christie, W. W. 1982. The preparation of derivatives of lipids. 
Pages 51-61 in W. W. Christie. Lipid analysis, 2nd edition. Pergamon Press, Oxford, UK.

Fernández-Palacios, H., M. S. Izquierdo, L. Robaina, A. Valencia, M. Salhi, and D. Montero. 1997. The effect of dietary protein and lipid from squid and fish meals on egg quality of broodstock for gilthead seabream (Sparus aurata). Aquaculture 148:233-246.

Fernández-Palacios, H., M. S. Izquierdo, L. Robaina, A. Valencia, M. Salhi, and J. Vergara. 1995. Effect of n-3 HUFA level in broodstock diets on egg quality of gilthead seabream (Sparus aurata L.). Aquaculture 132: 325-337.

Folch, J., M. Lees, and G. H. Sloane-Stanley. 1957. A simple method for the isolation and purification of total lipids from animal tissues. Journal of Biological Chemistry 276:497-507.

Gallagher, M. L., L. Paramore, D. Alves, and R. A. Rulifson. 1998. Comparison of phospholipid and fatty acid composition of wild and cultured striped bass eggs. Journal of Fish Biology 52:1218-1228.

Harel, M., A. Tandler, G. W. Kissil, and S. Applebaum. 1994. The kinetics of nutrient incorporation into body tissues of gilthead sea bream, Sparus aurata, females and subsequent effects on egg composition and egg quality. British Journal of Nutrition 72:45-58.

Harrell, R. M., and L. C. Woods, III. 1995. Comparative fatty acid composition of eggs from domesticated and wild striped bass (Morone saxatilis). Aquaculture 133:225-233.

Izquierdo, M. S., H. Fernández-Palacios, and A. G. J. Tacon. 2001. Effect of broodstock on reproductive performance in fish. Aquaculture 197:25-42.

March, B. E. 1993. Essential fatty acids in fish physiology. Canadian Journal of Physiology and Pharmacology 71 : 684-689.

Mazorra, C., M. Bruce, J. G. Bell, A. Davie, E. Alorend, N. Jordan, J. Rees, N. Papanikos, M. Porter, and N. Bromage. 2003. Dietary lipid enhancement of broodstock reproductive performance and egg and larval quality in Atlantic halibut (Hippoglossus hippoglossus). Aquaculture 227:21-33.

Mourente, G., and J. M. Odriozola. 1990. Effect of broodstock diets on lipid classes and their fatty acid composition in eggs of gilthead sea bream (Sparus aurata L.). Fish Physiology and Biochemistry 8:93-101.

Mustafa, T., and K. C. Srivastava. 1989. Prostaglandins (eicosanoids) and their role in ectothermic organisms. Advances in Comparative and Environmental Physiology 5:157-207.

Navas, J. M., M. Bruce, M. Thrush, B. M. Farndale, N. Bromage, S. Zanuy, M. Carrillo, J. G. Bell, and J. Ramos. 1997. The impact of seasonal alteration in the lipid composition of broodstock diets on egg quality in the European sea bass. Journal of Fish Biology 51:760-773.

Rottmann, R. W., J. V. Shireman, C. C. Starling, and W. H. Revels. 1988. Eliminating adhesiveness to white bass eggs for the hatchery production of hybrid striped bass. Progressive Fish-Culturist 50:55-57.

Sargent, J. R. 1995. Origin and functions of egg lipids: nutritional implications. Pages 353-372 in N. R. Bromage and J. R. Roberts, editors. Broodstock management and egg and larval quality. Blackwell Scientific Publications, London.

Sargent, J. R., J. G. Bell, M. V. Bell, R. J. Henderson, and D. R. Tocher. 1995. Requirement criteria for essential fatty acids. Journal of Applied Ichthyology 11:183-198.

SAS Institute. 2001. Statistical analysis system, version 8.1. SAS Institute, Cary, North Carolina.

Suresh, A. V., J. B. Rudacille, M. L. Allyn, V. Sheehan, R. J. Sheehan, and C. C. Kohler. 2000. Single injections of hCG or mGnRHa at low dosages induce ovulation in white bass. North American Journal of Aquaculture 62:87-94.

Tocher, D. R., and D. G. Harvie. 1988. Fatty acid composition of the major phosphoglycerides from fish neural tissues: (n-3) and (n-6) polyunsaturated fatty acids in rainbow trout (Salmo gairdneri) and cod (Gadus morhua) brains and retinas. Fish Physiology and Biochemistry 5: 229-239.

Tocher, D. R., and J. R. Sargent. 1987. The effect of calcium ionophore a23187 on the metabolism of and eicosapentaenoic acids in neutrophils from a marine fish rich in (n-3) polyunsaturated fatty acids. Comparative Biochemistry and Physiology 87B:733-739. 